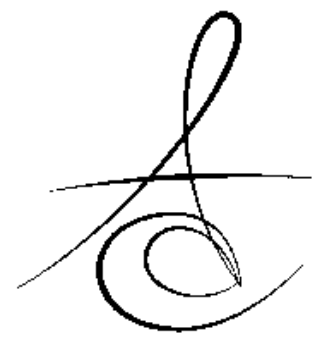

\title{
THE EFFECT OF CEMENT FILM THICKNESS ON THE BOND STRENGTH OF FIBER POST
}

\author{
FİBER POSTLARIN BAĞLANMA DAYANIMI ÜZERİNDE SİMAN \\ KALINLIĞININ ETKİSİ
}

Dr. Duygu KÜRKLÜ*

Prof. Dr. Nuran DİNÇKAL YANIKOĞLU**

Yrd. Doç. Dr. Bilal HOLOĞLU*

Makale Kodu/Article code: 2321

Makale Gönderilme tarihi: 20.06.2015

Kabul Tarihi: 15.07.2015

\section{ABSTRACT}

Objectives: The purpose of this in-vitro study was to evaluate the effect of 3-different post-space on the bond strength of fiber post.

Study design: Fifty-four extracted human maxillary incisors were selected and their roots were treated endodontically. The roots were prepared according to different post spaces (Torpan Drill ISO 100(D100), 120(D120) and Enapost Drill ISO 140(D140), and divided into three groups. Snowposts were used, and the posts were cemented with three different dual polymerized resin luting agents: Panavia $F, N X 3$ and Rely $X$. The specimens were subjected to a pullout test using a universal testing machine at a cross-head speed of $0.5 \mathrm{~mm} / \mathrm{min}$. The maximum force required to dislodge each post was recorded. Data were analyzed using the two way ANOVA and Tukey multiple comparisons tests.

Results: According to the results of Tukey test, the bond strength values of the Panavia $F$ luting cements was significantly higher in D120 post space; otherwise, there were no significant differences between Rely X and NX 3.

Conclusions: It had been seen that cement thickness affects the pullout strengths of fiber-reinforced posts. post

\section{ÖZET}

Amaç: Bu çalışmanın amacı fiber postların bağlanma dayanımına 3 farklı post aralığının etkisini değerlendirmektir.

Materyal ve Metod: Çekilmiş 54 adet üst kesici diş kullanıldı ve bu dişlere kök- kanal tedavisi uygulandı. Kök kanalları değişik boyutlarda post boşluklarına göre hazırlandı (Torpan Drill ISO 100(D100), 120(D120) ve Enapost Drill ISO 140(D140),Drill) ve 3 alt gruba ayrıldı. Fiberpostlar (Snowpost) 3 farklı kimyasal ve Işıla (dual)sertleşen rezin simanla (Panavia $F, N X 3$ and Rely X) simante edildi. Örneklere başlık hızı 0,5 $\mathrm{mm} / \mathrm{dk}$ olan universal test cihazıyla çekme testi uygulandı. Postları yerinden uzaklaştıran maksimum kuvvetler kayıt edildi. Veriler Two-way ANOVA ve Tukey testleri kullanılarak analiz edildi.

Bulgular: Tukey testi sonuçlarına göre Tropan D120 drill ile açılan post boşluklarında Panavia F ile simante edilen dişlerin değerlerinin en yüksek olduğu, buna rağmen Rely $X$ ve NX3 değerleri arasında istatistiksel olarak önemli bir farklılık olmadığı görülmüştür.

Sonuç: Siman kalınlığının fiberle güçlendirilmiş postların çekme kuvvetini etkilediği görülmüştür.

Anahtar Kelimeler: Bağlanma Dayanımı, Siman Kalınlığı, Post

\footnotetext{
${ }^{*}$ Ministry of Health, State Hospital of Dentistry, Konak, İzmir

${ }^{* *}$ Faculty of Dentistry, Department of Prosthodontics, Atatürk Unıversıty, Erzurum

${ }^{* * *}$ Faculty of Dentistry, Department of Prosthodontics, Gaziosmanpaşa University, Tokat
} 


\section{INTRODUCTION}

Endodontically treated teeth often require partial or complete coverage restorations according to the amount of remaining tooth structure. Root canal therapy is usually applied in teeth with pulpal infection resulting from extensive decay. Therefore, these teeth also suffer from loss of structural integrity. Caries, access cavity, and excessive removal of radicular dentine during endodontic treatment increase the risk of fracture. Therefore, restoration of these teeth should be considered for function and aesthetics. ${ }^{1}$

Post and core systems have been used to restore endodontically treated teeth for more than 250 years. $^{2}$ The use of prefabricated posts and resin restorative materials to fabricate post and core systems was introduced in the 1960 s. ${ }^{3}$ Numerous post systems have been used, including custom cast posts and pre-fabricated posts. Traditional prefabricated posts are made of metal. There are reports in the literature of poor post retention, potential for post and root fractures and risk of corrosion associated with conventional metallic dowel systems. 4-6 Toothcoloured pre-fabricated post and core systems such as fiber-reinforced composite (FRC) posts and zirconia ceramic posts have been used because the result of the increasing demand from patients and clinicians for aesthetic replications of the natural dentition. 7,8 The use of fiber-reinforced resin posts to restore endodontically treated teeth has gained popularity in the last few years. Most fiber posts consist of a resin matrix with reinforcing quartz or glass fibers. ${ }^{9}$

The causes of failure of endodontically treated incisors are loss of retention of post or crown, post distortion, root or post fracture and caries. The increase of retention through post application is definite, but the reinforcing effect of posts on the tooth remains controversial. ${ }^{10}$ Post material should have similar modulus elasticity to dentine to distribute the forces among the post and root. Fiber posts and composite cores, do not generate forces in the interface area. ${ }^{11}$ Previous studies have reported success rates of $95 \%$ to $99 \%$ with fiber-reinforced posts with no fracture of root. ${ }^{12-15}$

The other cause of failure in retention of fiber posts is the effect of post-space treatment. Zhang et al. ${ }^{16}$ reported that the apical push-out strength was affected by post-space treatment.
The most common cause of failure reported in in vivo studies was de-bonding between fiber postresin and/or resin-root canal dentin interfaces as a result of inadequate bond strength. ${ }^{17-18}$ Thus, there is a need to investigate and improve this treatment option. There have been some clinical studies related to the fracture resistance of Snowpost. ${ }^{11,19,20}$ Snowposts are made of zircon-rich glass fiber embedded in epoxy resin matrix. Gu XH et al. ${ }^{11}$ stated that fiber posts (Snowpost) have been shown to have superior fracture resistance and a favourable fracture mode. There are many studies in the literature related to the adhesive retention of the fiber post between root canals. 18,21-24 Numerous aspects of treatment, such as dentine bonding agents, luting cements, and polymerization modes have been shown to affect the retentive properties of fiber-reinforced posts. ${ }^{25-30}$

Information on the role of cement thickness and its influence on post-retentive strength is still not sufficiently available. ${ }^{31}$ Retrospective clinical studies have shown that de-bonding occurs when an increased cement film thickness is present. ${ }^{12,32}$ However, there is no consensus in the literature on the ideal film thickness of the resin cement to increase the post bond strength. Perez Be et al. ${ }^{33}$ suggested that an increase of the cement film thickness did not significantly affect the bond strength and that increased cement thickness surrounding the FRC post did not impair the bond strength.

The aim of this study was to evaluate the effect of different cement thicknesses on the bond strength of fiber posts. The resin cements can provide an acceptable retention of FRC posts with wider post space conditions.

\section{MATERIAL AND METHODS}

\section{Study Samples}

Fifty-four human intact single-rooted extracted teeth were used in the study. Radiographs were used to eliminate roots with curvature or calcified canals. Teeth with roots shorter than $10 \mathrm{~mm}$ or with defects or cracks were excluded. All external debris was removed with an ultrasonic scaler and fifty-four teeth were placed in 0.5 chloramine solution for no longer than 1 week after extraction. Before the experiments, the crown surface of each tooth was sectioned horizontally to the buccal cemento-enamel junction 
(CEJ) using a cylindrical diamond rotary cutting instrument (W\&H 4016) with water spray cooling. The pulps of all teeth were removed and then the endodontic treatment was performed chemomechanically. Canals were prepared with a HERO shaper (Micro-Mega, Besançon, France) using EDTA gel (File-Eze, Ultradent, USA) canal lubricant and $5.25 \% \mathrm{NaOCl}$ irrigation. Cleaning and shaping were considered as minimally adequate when an ISO file size of 25 with a 0.06 taper came to within 0.5-1.0 $\mathrm{mm}$ of the estimated working length. $1 \mathrm{~mL}$ of $15 \%$ liquid EDTA (Rehber Kimya, Istanbul, Turkey) for 1 minute, followed by $3 \mathrm{~mL}$ of $5.25 \% \mathrm{NaOCl}$ were used as final irrigating agents.

The enlarged canals were rinsed with distilled water and dried with paper points and obturated with gutta-percha using System B Heat Source and endodontic sealer (AH Plus Dentsply $\backslash$ Germany Lot: 0909001093).

The post spaces were prepared 24 hours after completing the endodontic procedures. Gutta-percha was removed with a warm endodontic plugger. The roots were divided into three groups of 18 specimens before completion of the post space preparations. In each group, a drill with a different diameter was used at a depth of $8 \mathrm{~mm}$ measured from the section roots' surface. Each group was shaped with three different drills including Torpan Drill ISO 100 (D100)-1,0 mm taper, Torpan Drill ISO 120 (D120)-1,2 mm taper and Enapost Drill ISO 140(D140)-1,4 mm taper. There are two different manufacturers because Torpan Drill has no $1.4 \mathrm{~mm}$ taper drill and the Enapost drill was used to substitute for a Torpan Drill ISO 140 that was commercially available. The three groups were then divided into three subgroups with 6 samples per group. Three different luting materials were used in this study and applied according to the manufacturer's recommendations (Table 1).

Before cementing, each composite post of 1.0 $\mathrm{mm}$ diameter (Snowpost $1.0 \mathrm{~mm}$ in diameter, taper $3 \%$ Lot no: 614130 , Carbotech, Ganges, France) was marked at a distance of $8 \mathrm{~mm}$ from the apical part, corresponding to the length of the post space preparation. All posts were then implanted in full depth in the prepared spaces using finger pressure, ensuring that all posts were at the same length extension from the orifice of the canal. Excess luting agent was immediately removed with a small brush.
An axial load of $5 \mathrm{~kg}$ was applied for 60 seconds using a custom-made loading apparatus to stabilise the fiber posts in the post space, as previously mentioned. Thirty minutes after the cementing procedures, all root specimens were stored in distilled water for 24 hours. The specimens were preserved in a saline solution at room temperature for 1 week.

The specimens were then embedded in autopolymerising acrylic resin (Imicryl Konya, Turkey, Lot: 09296) surrounded by plastic mould (Fig.1).

Parallelism between the post, canal, and acrylic resin block was obtained using a dental surveyor (Ney Surveyor System; The J.M. Ney Company Bloomfield, Conn, U.S.A).

Table 1. Materials used for luting and their characteristics.

\begin{tabular}{|c|c|c|c|c|}
\hline System & Component & $\begin{array}{l}\text { Batch } \\
\text { number }\end{array}$ & $\begin{array}{l}\text { Chemical } \\
\text { composition }\end{array}$ & Manufacturer \\
\hline $\begin{array}{l}\text { Panavia F } \\
2.0 \\
\text { Dual-cured } \\
\text { resin- } \\
\text { based } \\
\text { cement } \\
\end{array}$ & $\begin{array}{l}\text { * Paste A } \\
\text { * Paste B } \\
\text { * Oxyguard }\end{array}$ & 41246 & $\begin{array}{c}\text { MDP } \\
\text { adhesive monomer }\end{array}$ & $\begin{array}{c}\text { Kuraray } \\
\text { Medical, } \\
\text { Okayama, } \\
\text { Japan }\end{array}$ \\
\hline $\begin{array}{l}\text { Rely X ARC } \\
\text { Adhesive } \\
\text { resin } \\
\text { cement }\end{array}$ & $\begin{array}{l}\text { * Paste Shade } \\
\text { Universal in } \\
\text { Clicker }^{\mathrm{TM}} \\
\text { Dispenser }^{\text {Disper }} \\
\text { * Adper }{ }^{\mathrm{TM}} \text { Single } \\
\text { Bond } \\
\text { Adhesive } \\
\text { * Scotchbond } \\
\text { Phosphoric } \\
\text { Ptchant } \\
\text { Syringes } \\
\end{array}$ & 20090420 & $\begin{array}{c}\text { Methacrylate } \\
\text { monomers containing } \\
\text { phosphoric } \\
\text { acid groups } \\
\text { Alkaline (basic) fillers } \\
\text { Silanated fillers }\end{array}$ & $\begin{array}{c}\text { 3M } \\
\text { Espe,St.Paul, } \\
\text { USA }\end{array}$ \\
\hline $\begin{array}{c}\text { NX } 3 \\
\text { Nexus } \\
\text { Adhesive } \\
\text { resin } \\
\text { cement }\end{array}$ & $\begin{array}{l}\text { * Automix Dual- } \\
\text { Cure Syringe } \\
\text { Refills } \\
\text { * Light-Cure } \\
\text { Syringe Refills } \\
\text { * Try-In Gel } \\
\text { Syringe Refills }\end{array}$ & 2981915 & $\begin{array}{c}\text { Uncured Methacrylate } \\
\text { Ester Monomers }\end{array}$ & $\begin{array}{l}\text { Kerr,Avenue } \\
\text { Orange,USA }\end{array}$ \\
\hline $\begin{array}{l}\text { OptiBond } \\
\text { All-In-One }\end{array}$ & $\begin{array}{l}\text { * Adhesive } \\
\text { " Unidose } \\
\text { Devices }\end{array}$ & 3268853 & \begin{tabular}{|c} 
- Glycerol phosphate \\
fimethacrylate (GPDM) \\
- \\
self-etching adhesive \\
monomer \\
- Co-monomers \\
including mono- and \\
di-functional \\
methacrylate \\
monomers
\end{tabular} & $\begin{array}{l}\text { Kerr,Avenue } \\
\text { Orange, } \\
\text { USA }\end{array}$ \\
\hline $\begin{array}{l}\text { Clearfil SE } \\
\text { Bond }\end{array}$ & $\begin{array}{l}\text { * Self-etching } \\
\text { primer } \\
\text { * Bonding agent }\end{array}$ & 41718 & \begin{tabular}{|c} 
hydroxyethyl \\
methacrylate \\
$10-$ \\
Methacryloyloxydecyl \\
dihydrogen phosphate \\
Hydrophilic aliphatic \\
dimethacrylate \\
dl-Camphorquinone \\
Water \\
Accelerators
\end{tabular} & $\begin{array}{c}\text { Kuraray } \\
\text { Medical, } \\
\text { Okoyama, } \\
\text { Japan }\end{array}$ \\
\hline
\end{tabular}




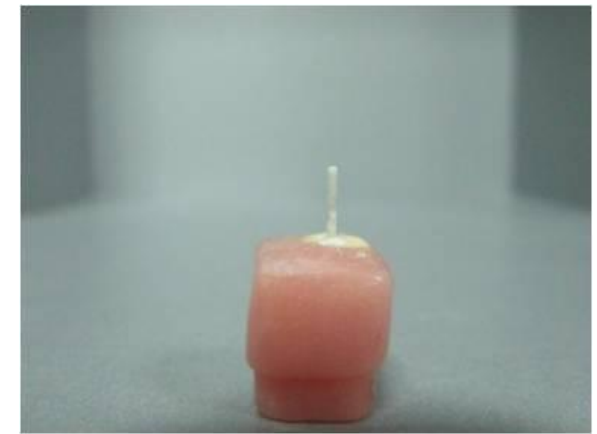

Figure 1 . Specimens were embedded in acrylic resin

The root aspect of each specimen, embedded in the acrylic resin box previously described, was fitted to the lower dynamometer clamp, while the coronal portion of each post was connected to the upper dynamometer clamp using a custom-made device (Fig.2).

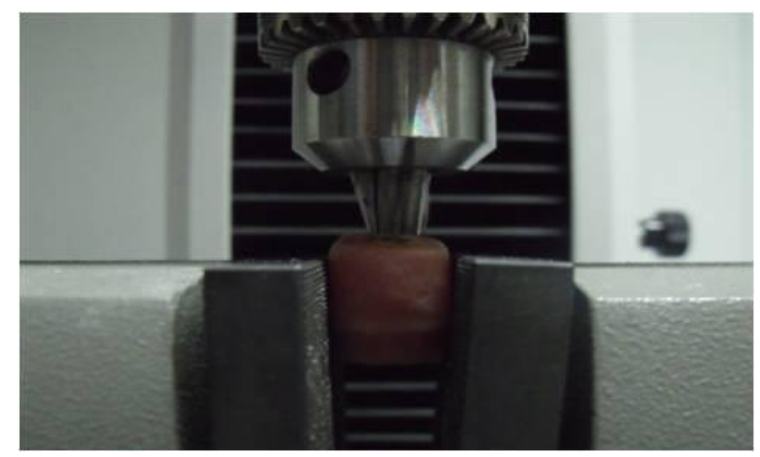

Figure 2. Specimens were connected to the lower dynamometer

A custom-made chain, consisting of 2 attached links, each having a diameter of $2.5 \mathrm{~cm}$, was interposed between the device and the upper clamp of the testing machine. The clamp applied to the fiber posts had an internal groove to hold the posts for testing and prevented crushing of the ends of the fiber posts. The specimens were then subjected to a pullout test using a universal testing machine INSTRON (Instron Corp, USA) at a crosshead speed of 5.0 $\mathrm{mm} / \mathrm{min}$, and the maximum force required to dislodge each post was recorded $(\mathrm{N})$.

\section{Statistical Analysis}

Data were analysed using the statistical software (Statistical Package for Social Sciences11.0; SPSS Inc, Chicago, III). The two-way ANOVA and the
Turkey multiple comparisons tests were performed by synthesising for 3 different groups $(a=0.5)$.

\section{RESULTS}

The results indicated that the mean pullout bond strength values in $\mathrm{N}$ and Standard deviation recorded for one of the experimental group D120(249.9) (83.76) was higher than that obtained for both the groups D100(185.0) (77.4) and D140(175.4) (56.9). The two way ANOVA verified that there was a significant difference between D120, and D100 and D140. $(P<0.05)$

Further analysis with the TUKEY test showed that D120 was significantly different in the Panavia $F$ group; otherwise, there were no significant values in either of the two groups, Rely X and NX 3. The mean bond strength values of the types of cements according to the cement thickness have been presented in Fig.3.

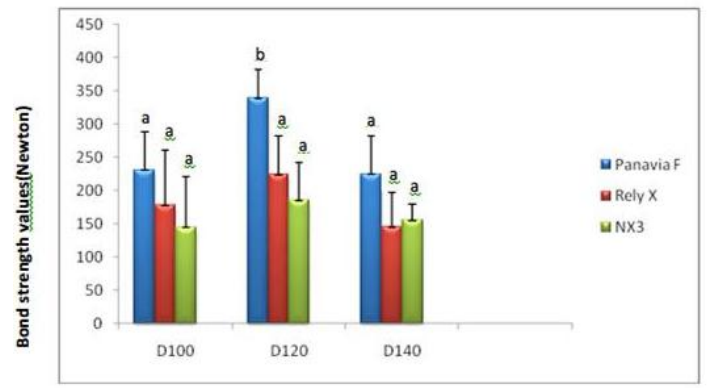

Figure 3. Mean bond strength values resulting in cement thickness

The highest bond strength values were shown in D120 cement thickness for all resin cements. The bond strength values were shown to be between the cement thickness and the three types of resin cement.

\section{DISCUSSION}

In the event of failure when restored with fiber-reinforced posts, teeth are more likely to be restorable. ${ }^{34-36}$ Ferrari et al. ${ }^{13}$ evaluated three types of fiber-reinforced posts over one to six years, and reported a failure rate of only $3.2 \%$ and the authors concluded that these posts can be used routinely in combination with bonding materials. It is very

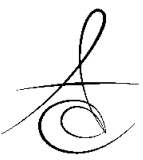


important to have very high potential for bonding to dentine and resin-based composite is very popular because of its mechanical properties. ${ }^{37}$ Resin cement has demonstrated improved retention of posts ${ }^{38}$ and decreased micro-leakage. ${ }^{39}$ Furthermore, thermocycling of resin cement used in thin film thickness is probably not as significant a problem as the other restorative procedures, and the modulus of elasticity of resin-based composite is similar to dentine. Bonding resin cement to the dentinal wall of the root canal space must be done carefully to improve bonding and minimise micro-leakage. ${ }^{37}$

Few studies have examined the effect of cement thickness on dowel retention. ${ }^{40}$ The supposition that cement thickness should be markedly increased opposes the generally accepted theory; however, some corroborative evidence has been reported. ${ }^{40-42}$ Assif and Ferber ${ }^{42}$ reported higher retentive strength in dowels placed with composite than in those placed with zinc phosphate cement, despite the fact that the dowel spaces for the composite cement were prepared with an oversized dowel space drill, whereas dowel spaces for the zinc phosphate cement were made with a matched drill (dowel of the same diameter was used for both groups). In a subsequent investigation, Assif and Bleicher ${ }^{41}$ compared several Parapost sizes using a composite cement thickness as high as $250 \mu \mathrm{m}$. All groups within this study were found to be equivalent in retentive strength.

Chan et al. 40 cemented Paraposts into 2 different diameters of dowel spaces using 4 types of cement. Dowel spaces of smaller diameter were prepared solely with the manufacturer's matched drill. The coronal $3 \backslash 4$ of the larger diameter preparations were made with a dowel drill of 2 sizes larger, creating a cement thickness of $250 \mu \mathrm{m}$ in this region. Additionally, all of the cements had significantly higher retentive strengths in the oversized canals. In this study, we used three resin cements (Panavia F, NX3 and RelyX) and compared post spaces $1.4 \mathrm{~mm}, 1.2 \mathrm{~mm}$ and $1.0 \mathrm{~mm}$. We eventually observed the higher bond strengths in the $1.2 \mathrm{~mm}$ post spaces.

Some retrospective clinical studies have shown that de-bonding occurs when the film thickness is too great $^{12,32}$ and it was proposed that the thinner the cement layer, the higher the retentive strength would be. ${ }^{30}$ Grandini et al. ${ }^{31}$ evaluated the resin cement thickness after luting anatomic posts and standardised fiber posts into root canal preparation. If a post does not fit well, especially at the coronal level, the resulting cement layer is too thick, and bubbles are likely to be present within it, predisposing it to post de-bonding. The formation of bubbles or voids, representing areas of weakness within the material, is less likely in a thin and uniform layer of cement. Moreover, they stated that polymerisation stress, developing within a relatively thin film of cement, would be minimal.

On the basis of the evaluations about post space and cement layer, this study was designed to test the thickness of resin cement film and its influence on the pullout strength of endodontic fiberreinforced posts. Intact natural central incisors are the best option to clinically simulate the treated teeth with endodontic post systems. ${ }^{36,43,44}$ The pullout test has also been used by several authors to assess the retention of posts. ${ }^{14,30}$ Mirmohammadi et al. ${ }^{45}$ stated that the highest push-out bond strength values were obtained when one incremental oversized post space was used. Clinically, fiber post space has to provide an optimum cement thickness (around $120 \mu \mathrm{m}$ ) for adequate cementation.Prospective and retrospective clinical studies have reported that the most common failure of endodontically treated teeth restored with endodontic post is the pullout of the cement/post/ composite-resin/restoration assembly. ${ }^{12,15}$ The mean push-out bond strengths were higher for light post and Glassix post where Variolink II resin cement was used for luting the fiber post, which is based on the total etch adhesive approach. In most of the samples, failure was observed between cement-dentine interface, followed by post-cement interface, which shows difficulty in bonding between post-cementdentine interface. ${ }^{46}$ Self-adhesive resin cements can provide an acceptable retention of FRC posts even in case of use with wider post space conditions. ${ }^{47}$

Considering these limits, the remarkable finding of this study is that, for the selected quartz fiberreinforced system post and dual cured adhesive resin cement (Panavia F 2.0), the highest bond strength values were not obtained when the thinnest cement was tested (D100), but when over-sized post spaces were used (D120). However, when the cement thickness increases (D140), it affects the retention quality of posts oppositely. These results are partially in agreement with those of D'Arcangelo et al. ${ }^{48}$ who 
demonstrated that an increase in cement thickness did not significantly affect the bond strength of fiber posts. On the other hand, cement film thickness did not significantly affect the pullout strengths when adhesive resin cements (Rely X ARC, NX3 Nexus) were used. Gomes et al. ${ }^{49}$ stated that lower resin cement thickness resulted in better fiber post adhesion, that is, in higher bond strength and less gap formation.

The stiffness of a material is related to its modulus of elasticity (E) and its geometry. ${ }^{50}$ It is a measure of the load needed to induce a given deformation in a material. The $\mathrm{E}$ of resin cement (approximately $8 \mathrm{GPa}$ ) is lower than that of dentine and fiber-reinforced posts. ${ }^{28}$

According to the results of this study, it appears that the cement thicknesses obtained in D120 had lower stiffness than that obtained in D100, thereby increasing the pullout strength values. It seems that only in the D140 group, the polymerisation stress and presence of microporosities ${ }^{22,30}$ negatively affected the pullout strength of the quartz posts.

\section{CONCLUSION}

Within the limitations of this in vitro study, the following conclusions were made:

1. The Panavia F resin cement was shown to have the highest bond strength values in oversized post space (cement thickness: 0,1-0,3)(D120)

2. There were no significant differences between resin cements (NX3 and RelyX) for different cement thicknesses.

\section{Conflict of interests}

No author had competing or conflicting interests during the duration of this study.

\section{REFERENCES}

1. Mannocci F, Bertelli E, Sherriff M, Watson TF, Pitt Ford TR. Three-year clinical comparison of survival of endodontically treated teeth restored with either full cast coverage or with direct composite restoration. 2002. International endodontic journal 2009;42:401-5.

2. Tylman SD. Theory and Practice of Crown and Bridge Prosthesis 2ed. St. Louis: MO, Mosby; 1947. p. 1-13.
3. Federick DR. An application of the dowel and composite resin core technique. The Journal of prosthetic dentistry 1974;32:420-4.

4. Trabert KC, Cooney JP. The endodontically treated tooth. Restorative concepts and techniques. Dental clinics of North America 1984;28:923-51.

5. Goodacre CJ, Spolnik KJ. The prosthodontic management of endodontically treated teeth: a literature review. Part I. Success and failure data, treatment concepts. Journal of prosthodontics : official journal of the American College of Prosthodontists 1994;3:243-50.

6. Silness J, Gustavsen F, Hunsbeth J. Distribution of corrosion products in teeth restored with metal crowns retained by stainless steel posts. Acta Odontol Scand 1979;37:317-21.

7. Koutayas SO, Kern M. All-ceramic posts and cores: the state of the art. Quintessence international 1999;30:383-92.

8. Stewardson DA. Non-metal post systems. Dental update 2001;28:326-32, 34, 36.

9. Perdigao J, Gomes G, Augusto V. The effect of dowel space on the bond strengths of fiber posts. Journal of prosthodontics : official journal of the American College of Prosthodontists 2007;16:15464.

10. O'Keefe $\mathrm{KL}$, Miller $\mathrm{BH}$, Powers JM. In vitro tensile bond strength of adhesive cements to new post materials. The International journal of prosthodontics 2000;13:47-51.

11. Gu XH, Kern M. Fracture resistance of crowned incisors with different post systems and luting agents. Journal of oral rehabilitation 2006;33:91823.

12. Ferrari M, Vichi A, Garcia-Godoy F. Clinical evaluation of fiber-reinforced epoxy resin posts and cast post and cores. American journal of dentistry 2000;13(Spec No):15-8.

13. Ferrari M, Vichi A, Mannocci F, Mason PN. Retrospective study of the clinical performance of fiber posts. American journal of dentistry 2000;13(Spec No):9B-13B.

14. Malferrari S, Monaco C, Scotti R. Clinical evaluation of teeth restored with quartz fiber-reinforced epoxy resin posts. The International journal of prosthodontics 2003;16:39-44.

15. Monticelli F, Grandini S, Goracci C, Ferrari M. Clinical behavior of translucent-fiber posts: a 2-

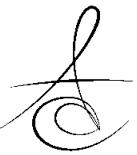


year prospective study. The International journal of prosthodontics 2003;16:593-6.

16. Zhang $L$, Huang $L$, Xiong $Y$, et al. Effect of postspace treatment on retention of fiber posts in different root regions using two self-etching systems. European journal of oral sciences 2008;116:280-6.

17. Aksornmuang J, Foxton RM, Nakajima M, Tagami J. Microtensile bond strength of a dual-cure resin core material to glass and quartz fiber posts. Journal of dentistry 2004;32:443-50.

18. Prisco D, De Santis R, Mollica F, et al. Fiber post adhesion to resin luting cements in the restoration of endodontically-treated teeth. Operative dentistry 2003;28:515-21.

19. Adanir N, Belli S. Stress analysis of a maxillary central incisor restored with different posts. European journal of dentistry 2007;1:67-71.

20. Adanir N, Belli S. Evaluation of different post lengths' effect on fracture resistance of a glass fiber post system. European journal of dentistry 2008;2:23-8.

21. Boschian Pest L, Cavalli G, Bertani P, Gagliani M. Adhesive post-endodontic restorations with fiber posts: push-out tests and SEM observations. Dental materials : official publication of the Academy of Dental Materials 2002;18:596-602.

22. Bouillaguet $S$, Troesch S, Wataha JC, et al. Microtensile bond strength between adhesive cements and root canal dentin. Dental materials : official publication of the Academy of Dental Materials 2003; 19:199-205.

23. Ferrari M, Mannocci F, Vichi A, Cagidiaco MC, Mjor IA. Bonding to root canal: structural characteristics of the substrate. American journal of dentistry 2000;13:255-60.

24. Torbjorner A, Karlsson S, Syverud M, HenstenPettersen A. Carbon fiber reinforced root canal posts. Mechanical and cytotoxic properties. European journal of oral sciences 1996;104:60511.

25. Akgungor G, Akkayan B. Influence of dentin bonding agents and polymerization modes on the bond strength between translucent fiber posts and three dentin regions within a post space. The Journal of prosthetic dentistry 2006;95:368-78.
26. Ferrari M, Vichi A, Grandini S, Goracci C. Efficacy of a self-curing adhesive-resin cement system on luting glass-fiber posts into root canals: an SEM investigation. The International journal of prosthodontics 2001;14:543-9.

27. Kalkan M, Usumez A, Ozturk AN, Belli S, Eskitascioglu G. Bond strength between root dentin and three glass-fiber post systems. The Journal of prosthetic dentistry 2006;96:41-6.

28. Lassila LV, Tanner J, Le Bell AM, Narva K, Vallittu PK. Flexural properties of fiber reinforced root canal posts. Dental materials : official publication of the Academy of Dental Materials 2004;20:29-36.

29. Sahafi A, Peutzfeld A, Asmussen E, Gotfredsen K. Effect of surface treatment of prefabricated posts on bonding of resin cement. Operative dentistry 2004;29:60-8.

30. Valandro LF, Filho OD, Valera MC, de Araujo MA. The effect of adhesive systems on the pullout strength of a fiberglass-reinforced composite post system in bovine teeth. The journal of adhesive dentistry 2005;7:331-6.

31. Grandini S, Goracci C, Monticelli F, Borracchini A, Ferrari M. SEM evaluation of the cement layer thickness after luting two different posts. The journal of adhesive dentistry 2005;7:235-40.

32. Fredriksson M, Astback J, Pamenius M, Arvidson K. A retrospective study of 236 patients with teeth restored by carbon fiber-reinforced epoxy resin posts. The Journal of prosthetic dentistry 1998;80:151-7.

33. Perez BE, Barbosa SH, Melo RM, et al. Does the thickness of the resin cement affect the bond strength of a fiber post to the root dentin? The International journal of prosthodontics 2006;19:606-9.

34. Akkayan B, Gulmez T. Resistance to fracture of endodontically treated teeth restored with different post systems. The Journal of prosthetic dentistry 2002;87:431-7.

35. Cormier CJ, Burns DR, Moon P. In vitro comparison of the fracture resistance and failure mode of fiber, ceramic, and conventional post systems at various stages of restoration. Journal of prosthodontics : official journal of the American College of Prosthodontists 2001;10:26-36.

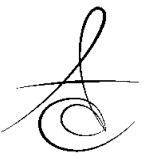


36. Newman MP, Yaman P, Dennison J, Rafter M, Billy E. Fracture resistance of endodontically treated teeth restored with composite posts. The Journal of prosthetic dentistry 2003;89:360-7.

37. Cheung W. A review of the management of endodontically treated teeth. Post, core and the final restoration. Journal of the American Dental Association 2005;136:611-9.

38. Varela, S.G., et al., In vitro study of endodontic post cementation protocols that use resin cements. J Prosthet Dent, 2003;89: 146-53.

39. Reid LC, Kazemi RB, Meiers JC. Effect of fatigue testing on core integrity and post microleakage of teeth restored with different post systems. Journal of endodontics 2003;29:125-31.

40. Chan FW, Harcourt JK, Brockhurst PJ. The effect of post adaptation in the root canal on retention of posts cemented with various cements. Australian dental journal 1993;38:39-45.

41. Assif D, Bleicher S. Retention of serrated endodontic posts with a composite luting agent: effect of cement thickness. The Journal of prosthetic dentistry 1986;56:689-91.

42. Assif D, Ferber A. Retention of dowels using a composite resin as a cementing medium. The Journal of prosthetic dentistry 1982;48:292-6.

43. Mendoza DB, Eakle WS, Kahl EA, Ho R. Root reinforcement with a resin-bonded preformed post. The Journal of prosthetic dentistry 1997;78:10-4.

44. Sirimai S, Riis DN, Morgano SM. An in vitro study of the fracture resistance and the incidence ofvertical root fracture of pulpless teeth restored with six post-and-coresystems. The Journal of prosthetic dentistry 1999;81:262-9.

45. Mirmohammadi H, Gerges E, Salameh Z, Wesselink $P R$. Effect of post diameter and cement thickness on bond strength of fiber posts. Quintessence Int. 2013; 44(10):801-10. doi: 10.3290/j.qi. a30179.

46. Kadam A, Pujar M, Patil C. Evaluation of push-out bond strength of two fiber- reinforced composite posts systems using two luting cements in vitro. J Conserv Dent. 2013 ;16:444-8. doi: 10.4103/09720707.117522.
47. Nova V, Karygianni L, Altenburger MJ, Wolkewitz M, Kielbassa AM, Wrbas KT. Pull-out bond strength of a fiber-reinforced composite postsystem luted with self-adhesive resin cements. J Dent. 2013; 41:1020-6. doi: 10.1016/j.jdent. 2013.08. 011. Epub 2013 Sep 2.

48. D'Arcangelo C, Cinelli M, De Angelis F, D'Amario M. The effect of resin cement film thickness on the pullout strength of a fiber-reinforced post system. The Journal of prosthetic dentistry 2007;98:193-8.

49. Gomes GM, Rezende EC, Gomes OM, Gomes JC, Loguercio $A D$, Reis $A$. Influence of the resin cement thickness on bond strength and gap formation of fiber posts bonded to root dentin. J Adhes Dent. 2014; 16:71-8. doi: 10.3290/ j.jad.a30878.

50. Pilo R, Cardash HS, Levin E, Assif D. Effect of core stiffness on the in vitro fracture of crowned, endodontically treated teeth. The Journal of prosthetic dentistry 2002;88:302-6.

\section{Yazışma Adresi:}

Prof.Dr. Nuran Yanıkoğlu

Atatürk University, Faculty of Dentistry

Prosthodontics Departments

Erzurum-TURKEY

Phone : 904422311780

Fax : 904422360945

E-Mail : nyanikoglu@yahoo.com dt.duyguk@hotmail.com bilalhologlu@hotmail.com, bilal.hologlu@gop.edu.tr 